\title{
Illegal Waste Transport and the Czech Republic: An Environmental Sociological Perspective
}

\author{
BENJAMIN J. VAIL* \\ Masaryk University, Brno
}

\begin{abstract}
In late 2005 Czech authorities first began to discover substantial amounts of municipal waste illegally transported from Germany to the Czech Republic. The dumping of more than 30000 tonnes of German waste in 'black dumps' throughout the Bohemian countryside raised social, economic, and political questions about how to mitigate the negative human health and environmental impacts and prevent dumping in the future. In addition to prompting practical policy questions, the situation challenges sociologists to theorise the causes, effects, and possible responses to the problem. This article draws on the environmental sociological Treadmill of Production (ToP) theory to examine the role of the state in managing the crisis. The author presents the history of the Bohemian illegal waste problem and then describes and analyses relevant waste management policies in the Czech Republic, Germany, and the European Union in the light of the ToP theory, which hypothesises that environmental degradation is caused primarily by institutional political-economic forces, and that the protection of environmental quality can be achieved only through structural reform. The dilemma of illegal waste shipment highlights the difficult role of the government, which must balance its responsibilities to protect environmental quality and human health and promote commerce and economic growth in an international context. Data from interviews and documentary analysis are used to describe the case study and test the ToP theory. The author concludes that while the ToP theory is useful for analysing the illegal waste issue by highlighting the structural character of the problem, some refinement of the theory may be necessary to better understand this case study.
\end{abstract}

Keywords: Czech Republic, environmental policy, environmental sociology, Treadmill of Production theory, waste management

Sociologický časopis/Czech Sociological Review, 2007, Vol. 43, No. 6: 1195-1211

\section{Introduction}

The story of recent illegal transport of German waste into the Czech Republic begins in 2005. But rather than being a new phenomenon limited in scope to two nations, the situation fits an historical pattern of illegal international German waste

\footnotetext{
* Direct all correspondence to: Benjamin J. Vail, Sociology Department, Masaryk University, Joštova 10, 60200 Brno, Czech Republic, e-mail: vail@fss.muni.cz.
}

(C) Sociologický ústav AV ČR, v.v.i., Praha 2007 
shipments and raises questions about the broader policy context for regulating waste transport in Europe.

This article seeks to place the phenomenon of illegal transport and disposal of municipal waste from Germany into the Czech Republic in sociological perspective. First, the environmental sociological Treadmill of Production (ToP) theory is introduced to provide a framework for analysis. Then, methods used for the research are explained. The article then presents empirical evidence describing the recent incidence of illegal waste shipment and disposal, including an overview of relevant policies. The article concludes with a critical analysis of the applicability of the ToP perspective to this case study.

\section{Theory}

\section{The sociology of waste management}

The topics of international waste shipment and waste management in general have not been the focus of much social science research. Waste management is most often seen as a technical issue to be handled by engineers, as an administrative issue to be handled by regulators, or as a political-legal topic to be handled by policy-makers and law enforcement. But a key focus of social science research is the nature of modern industrial society, which includes an examination of patterns of production and consumption. What often goes unnoticed is the fact that all social and economic activities entail the production of waste that must somehow be disposed. Factories produce not only goods, but pollutants and scrap materials. Virtually everything we consume - from food to clothes to autos to mobile phones - will end up in a landfill or otherwise be thrown away. But where is 'away'? Where does the stuff go after we put it in the rubbish bin?

The fact is that waste never goes away. It may be reused, recycled, burned, or buried - but all these processes have their social and environmental costs and benefits. In his novel Love and Garbage, Ivan Klíma [1990] observed, 'No matter ever vanishes. It can, at most, change its form. Rubbish is immortal, it pervades the air, swells up in water, dissolves, rots, disintegrates, changes into gas, into smoke, into soot, it travels across the world and gradually engulfs it'.

The continual production of waste raises serious public policy issues. European researchers have noted the environmental and sociological significance of waste management: 'The production of waste is closely tied to other issues, including consumption patterns, lifestyle, jobs and income levels, as well as a host of other socio-economic and cultural factors. Therefore, it is important to view waste management within the larger arena of socio-economic development and resource management. ...Waste management is recognized as a key area in environmental protection, as it is where the outputs of production, distribution, and consumption interface with the natural environment - soil, air, water, climate' [Hansen, Christopher and Verbuecheln 2002: 3]. 
Over time - paralleling other social changes such as rising income, urbanisation, and an increasing division of labour in the Western world - a rational municipal garbage collection system came into existence in most European settlements. As with the provision of other services, garbage collection today - whether fulfilled by the public or the private sector - has in many societies proven to be susceptible to corruption [Cowan and Century 2003; Massari 2003]. The illegal trade in waste has been shown to exist all over the world, and is driven mainly by the lure of big profits. People want to be rid of their garbage, and many companies are happy to provide the service - legally or illegally.

The question of how to manage waste generated by economic activity has been the subject of environmental sociology theory for some time. Treadmill of Production theorists take a critical view of the economic values and practices that have led to environmental degradation in the modern world, including the production of wastes - a situation which they theorise emerges from the fact that industrialised society is based on an ideology of constant economic growth.

\section{ToP and waste}

The ToP theory is a critical political economic approach to understanding society-environment relations, especially the causes, effects, and possible solutions of environmental problems. The treadmill perspective suggests that illegal waste transport is a systemic problem. The logic of constant economic growth produces ever-increasing amounts of waste, and in a globalised economy waste export is predictable, especially within a borderless Europe. European Union policies and principles intended to promote sustainable development may be overwhelmed by competing economic interests, and individual states may not only be constrained in their ability to control environmentally destructive behaviour, but have difficulty balancing economic and ecological obligations. The key claim of the ToP is 'that capital-intensive economic expansion is intrinsic to capitalist-market societies, due to the structure of the economy and the role of the state, and involves an intrinsic tendency toward environmental degradation' [Buttel 2004: 330-332].

The 'treadmill' model, as initially laid out in Allan Schnaiberg's The Environment [1980], is a metaphor for the functioning of the modern industrial capitalist political economy. ToP theorists observe that the economy is characterised by constant expansion and driven by the maximisation of profit by private interests. Such a system has social and ecological consequences, which include growing social inequality and conflict, and ever-increasing pollution and raw material extraction.

Equally important is the exercise of power and manipulation of the political system towards growth for the benefit of economic and political elites. 'Big government' and 'big business' interests are often aligned to promote economic expansion at almost any cost [Gould, Pellow and Schnaiberg 2004: 297]. Research 
to test the ToP theory empirically has demonstrated, for example, that corporate involvement in waste management and recycling systems can contribute to social and ecological problems by undermining local government authority and creating hazardous work conditions [Weinberg, Pellow and Schnaiberg 2000].

The ToP theory focuses on the production side of the economy because this is the physical location of the first interaction between society and nature. Consumption follows production, and while consumption has obvious environmental impacts it is a less direct relationship than that between production and the environment. In the United States, for example, household garbage amounts to only about two percent of all waste nationwide. This includes common items such as kitchen scraps, textiles and furnishings, yard trimmings, packaging, and electronics. Most waste is produced in resource extraction and industrial and manufacturing processes [Royte 2005: 282-283]. Similarly, of the total annual volume of waste generated in the Czech Republic in 2005 (more than 29.8 million tonnes), only about 4.4 million tonnes, or about $15 \%$, was municipal waste. The majority was instead industrial, mining, and agricultural waste [Czech Ministry of the Environment 2007, Table A3.1].

ToP theorists observe an unequal power dynamic between producers and consumers. Not only do individuals have little choice but to buy what is produced, but producers use advertising and influence the mass media to shape consumer preferences and increase demand. This helps perpetuate the treadmill cycle of ever-increasing economic activity and ever-increasing waste production [Schnaiberg and Gould 1994; Gould, Pellow and Schnaiberg 2004]. The state plays an important role in maintaining and supporting this pattern of production and consumption. In fact, the state faces contradictory imperatives: it is responsible for protecting human health and the environment, but it also exists to promote economic welfare. Thus the state as environmental regulator - the so-called environmental state - is pulled in different directions. When these roles come into conflict, politicians and bureaucrats, owing to ideological belief and/or material concerns, generally err on the side of economic growth rather than environmental protection. Both labour and capital tend to prioritise economic growth, and such interests exert political pressure through lobbying and campaign donations [Schnaiberg, Pellow and Weinberg 2002].

To protect the environment, the response to producer power must be political, says Schnaiberg, who theorises that an effective counterbalance can only be achieved when individual consumer-citizens organise themselves into social movements and non-governmental organisations to pressure the public and private sectors. Collective action, he says, is more effective for environmental protection than individuals making private lifestyle choices. Positive change will only occur through conflict with the political and economic decision-making elite. 'Radical restructuring of the political economy' is necessary [Gould, Pellow and Schnaiberg 2004]. 
Such views have clear implications for waste management policy. Europeans should not rely simply on market mechanisms or environmental education to change individual and collective practices that impact the environment. Furthermore, environmental problems occur within the context of a globalised economy. For example, the globalisation process may have allowed some wealthy nations to adopt strict environmental policies at the expense of developing nations. Many polluting industries have been moved to third world locations, allowing the global north to export environmental risk to the south. ToP theorists observe that the treadmill has become 'transnationalised' because investment capital flows freely to areas where production costs are lowest [Gould, Pellow and Schnaiberg 2004].

Developing nations are attractive to international capital for several obvious reasons. Cheap labour, weak environmental laws, and corrupt business and government can lower the cost of production. In essence, multinational corporations achieve bigger profits by externalising more of the costs of production. In addition to facilitating ecological destruction, this phenomenon often has the effect of weakening the ability of locals to organise to counter-treadmill interests.

As a nation peripheral to the economic powerhouse of Western Europe, in many ways the Czech Republic has benefited from globalisation. With a relatively low-priced and well-educated work force, the nation has attracted foreign investment. New industries have provided well-paid skilled jobs and often use techniques that are less polluting than those of communist-era firms. But the Czech Republic is also experiencing some downsides of globalisation, and illegal waste shipment is one example. In line with the ToP theory, as new strict regulations come into force and waste treatment costs rise in Germany, it is natural for Germans to seek cheaper disposal alternatives. There was strong evidence already in the early 1990s that the shipment of waste to Central and Eastern Europe could have negative social and ecological effects [Dopp 1997; Andersson 1999]. The problem of illegal or 'black' dumps in Bohemia has highlighted the strengths and weaknesses of the current waste policies intended to regulate this trade.

\section{Methods}

This research about the causes and effects of illegal waste shipments into the Czech Republic began in the winter of 2006 with the cataloguing and analysis of news media reports about the discoveries of black dumps. The sources of information were expanded to include a variety of documents, including government reports and statements, academic papers, articles, and books. These documents were selected to provide information about the context of existing and proposed waste management and environmental protection regimes in the Czech Republic, Germany, and the EU. Later, semi-structured interviews with key informants and correspondence with Czech government officials were conducted to elicit information about the public policy-making process and the investigations into 
illegal activity. The author attempted to contact German officials and experts to learn more about German perspectives on the issues, but such inquiries received no replies. Information and analysis about German waste management, environmental protection, law enforcement, and transport issues are instead based on government documents, media reports, and other sources.

\section{Findings}

\section{Illegal waste transport and the Czech Republic}

In the autumn of 2005 and the winter of 2006, Czech authorities discovered that significant amounts of municipal waste were being illegally transported into Bohemia from Germany. Illegal transports continued to be intercepted by police and customs officials throughout 2007. ${ }^{1}$ The waste was detected primarily through the interception and inspection of trucks headed to black dump sites. By the spring of 2006, the Czech Environmental Inspectorate (CEI) determined that much of the waste came from German federal states, including Baden-Württemberg, Bavaria, Brandenburg, Lower Saxony, North Rhine-Westphalia, Rhineland-Palatinate, Saxony, Saxony-Anhalt, and Thuringia. ${ }^{2}$

Black dumps were found in a variety of locations within the Czech Republic, mostly in North Bohemia near the German border. A total of twenty-six illegal dumps were documented in the media as containing waste that appeared to have originated in Germany. The sites where waste was dumped illegally included open fields and lots, farm buildings, a vacated military airfield, warehouses, and even legal landfills. In sum, the CEI identified about 30000 tonnes of alleged illegal German waste dumped in Bohemia. Of this amount, about 15000 tonnes was ultimately landfilled within the Czech Republic by the summer of 2006, and only about 7000 tonnes was satisfactorily proven to be of German origin. ${ }^{3}$

In January 2006, Czech authorities discovered what was to become perhaps the most notorious dump, near the village of Libčeves in North Bohemia. There inspectors found around 4000 tonnes of municipal waste from Germany - the equivalent of about 200 tractor-trailer truckloads - stored out in the open and in a barn. Some of the waste was hazardous, and the improper storage attracted pests and threatened to contaminate the soil and water. To make matters worse, the dump was set ablaze on three different occasions during the spring, releasing smoke into the air over the town [ČTK 2006a]. It is believed the waste was de-

\footnotetext{
${ }^{1}$ Personal interview with Lubomír Doskočil of the Czech Customs Administration in Prague, Czech Republic, 25 June 2007.

2 Personal interview with Jitka Jenšovská of the Czech Environmental Inspectorate in Prague, Czech Republic, 2 August 2006.

${ }^{3}$ Personal interview with Jitka Jenšovská of the Czech Environmental Inspectorate in Prague, Czech Republic, 19 May 2006.
} 
liberately lit to destroy evidence of the crime. While there was evidence that the materials in Libčeves originated in Saxony-Anhalt, it was difficult to prove who should be responsible for cleaning them up. When it was finally agreed that the government of Saxony-Anhalt should repossess the waste, only about 750 tonnes were taken back to Germany, and the remainder was landfilled in the Czech Republic [ČTK 2006e]. A Czech waste hauler was fined ten million Czech crowns for creating the dump, but avoided payment by declaring bankruptcy.

Czech authorities responded in several ways to the dumps found throughout Bohemia, including through regulatory reforms and both cooperation and confrontation with their German counterparts. At first, the Czech government considered banning all waste imports [ČTK 2006b]. A rule broadening the list of wastes requiring permits to enter the country took effect in March 2006 but was almost immediately abandoned as impracticable. Additionally, the rule was deemed at variance with EU waste shipment regulations and interfered with the legitimate cross-border waste trade critical to the Czech recycling industry.

More border checks were combined with higher potential fines for violators. Parliament raised the maximum fine for improper waste import from ten million to fifty million Czech crowns [ČTK 2006h]. Fines were imposed on several companies, and numerous suspects were arrested. By late April 2006, five Czechs and one German had been arrested for involvement in the illegal transports [ČTK 2006d]. In total, four Czech companies were fined between a quarter of a million and ten million crowns for their participation in the smuggling. By June 2006, the CEI announced plans to seek prosecution of up to twenty German companies [ČTK 2006g].

During the crisis a special German-Czech environmental commission was created and a 'Roadmap for the take back/disposal or recovery of illegally shipped German waste to the Czech Republic' was signed by the environment ministries of both nations in early May 2006. Despite this agreement on paper, however, the Czechs felt that the German authorities were not particularly forthcoming with assistance in solving the crime and determining responsibility for clean-up. ${ }^{4}$ At the international level, the Czech Republic advocated stricter regulation of the waste trade, both in Brussels and in solidarity with its neighbours in the Visegrád group, which comprises the Czech Republic, Hungary, Poland, and Slovakia [ČTK 2006f].

\section{A review of relevant policies}

There are several important policies and principles that guide EU and national waste management practices that are key to understanding the illegal transport problem.

${ }^{4}$ Personal interview with Jitka Jenšovská of the Czech Environmental Inspectorate in Prague, Czech Republic, 18 July 2006. 


\section{European Union policy}

The three big directives intended to define EU waste policy and encourage ecofriendly waste management practices are the Framework Directive (75/442/EEC, amended by $91 / 689 /$ EEC), the Packaging Waste Directive (94/62/EC), and the Landfill Directive (99/31/EC). The Waste Shipment Regulation (259/93/EC) governs the international waste movement. A myriad of other directives regulating specific waste issues, such as electronics waste and motor vehicle disposal, also took effect in recent years. Together these directives have shaped the context in which German and Czech waste management practices have developed since 1990. There is an interesting and perhaps ironic history to this policy-making process, since over a period of many years Germany has pressured the EU to adopt stricter waste policies. For example, the Packaging Waste Directive (94/62/EC) is based heavily on German policies for the collection and recycling of packaging. At the same time, recent Czech environmental policy reform has been motivated almost entirely by the need to conform to requirements involved with becoming an EU member state in May 2004 [Vail 2005]. Thus, Czech restrictions on the import and disposal of foreign waste have been driven at least indirectly by German initiatives.

Over the decades, numerous principles expressed in EU law have been intended to guide environmental policy in general. Several have clear relevance for the areas of waste management and transportation, such as the polluter pays principle (PPP) and the proximity principle. The PPP says that those who produce pollution are legally and financially responsible for the clean-up of the pollution. The aim is to internalise environmental costs as an incentive to better practices [McCormick 2001: 75]. The proximity principle states that environmental problems should be dealt with as close to the source of the problem as possible. In the context of waste management, the principle calls for waste to be treated and disposed of as near to its place of origin as possible, with the goal of regional and national self-sufficiency in waste generation, treatment, and disposal.

The waste hierarchy is another concept that guides EU waste management policy. It establishes an order of priority for the treatment of waste, which includes, in order of most preferred to least preferred options: waste prevention and reduction, reuse, recycling, recovery, and disposal [Betts, Novak and Young 2002: 13; Hansen et al. 2002: 4].

The overarching policy context for handling the Czech-German waste transport dispute was set by Waste Shipment Regulation (WSR). Titled 'Council regulation 259/93 on the supervision and control of shipments of waste within, into and out of the European Union', it transposed the Basel Convention on hazardous waste shipments and OECD regulations on waste transport. The regulation classifies wastes by risk, requires prior authorisation for the shipment of waste, and stipulates that unauthorised waste must be returned to its source of origin or otherwise properly disposed of. Wastes on the 'green list' - materials to be recy- 
cled or reused, such as plastic bottles or paper - can be transported freely, but restrictions apply to more hazardous amber and red list materials [European Commission 2005]. The WSR specifies the process for resolving illegal transboundary waste transport. If waste is determined to have been transported illegally, the 'notifier' - the source of the waste - must take responsibility for its return and proper disposal. The 'competent authorities' of the states involved - usually the national Environment Ministry - are required to cooperate in determining where the waste originated and to take the appropriate steps for remediation.

A new WSR (1013/2006), which is described as 'simpler but a bit stricter' than 259/93, came into force on 12 July 2007 [Zegnál 2006]. In late 2005 the European Parliament approved the new regulation, intended to harmonise EU policy with new international standards and streamline the waste transport authorisation process.

\section{Czech policy}

The Waste Act of 2001 and the national Waste Management Plan (WMP) of 2003 set the context for Czech waste policy. Basically, these policies harmonise Czech law with EU requirements. The Waste Act prohibits the import of waste for disposal or energy production but allows wastes to be imported for recycling or further processing. Regarding waste imports, in accordance with EU law, the Czech government requires financial guarantees, or a deposit, to be paid in advance by the hauling companies. The deposit (or evidence of proper insurance) is held by the government and released back to the importer when proper proof of delivery and treatment is shown. However, black market haulers rarely conform to this requirement. The WMP calls for the gradual elimination of barriers to the free movement of non-hazardous wastes intended for recovery, the minimisation of transboundary movements of waste for disposal, and cooperation with neighbouring countries to control the import and export of wastes [Czech Ministry of the Environment 2003: Chapter $3.5 \mathrm{a}-\mathrm{f}]$.

\section{German policy}

Germany has an international reputation for strict and innovative waste management practices. For example, the 'Green Dot' recycling programme started in the 1990s under the Duales System Deutschland was a pathbreaking policy designed to increase recycling rates and reduce waste production. The Green Dot has become a model for recycling programmes throughout Europe, including the Czech Republic, where it operates under the Eko-kom company. The Closed Substance Cycle and Waste Management Act (CSCWMA), which took effect in October 1996, codified the polluter pays principle and introduced incentives for material- and energy-efficient production processes and re-use of materials. In 
2001, a new waste storage ordinance went into force in Germany. Under this ordinance, municipal waste may no longer be landfilled directly. Instead, rules requiring waste to be incinerated or subjected to mechanical-biological treatment before final disposal came into effect on 1 June 2005. These processes reduce the volume of waste to be interred. Poorly lined landfills are to be gradually closed down by 2009.

The question arises whether German legislators and regulators considered the immediate practical implications of the new rules. The landfill ordinance granted no exceptions for untreated waste to be landfilled. While Hempen [2005] said there was 'little data available' to predict the country's waste storage capacity after 1 June 2005, she cited data suggesting a national 'capacity shortfall of at least 2 million tons' could be expected. Among the options suggested by the German government to handle the overflow was 'export of waste'. Before the 2005 rules took effect, export of waste was among the possible solutions considered by the German government to handle the overflow [Hempen 2005].

When the rules were applied, 200 of 333 official landfill sites were closed, driving up waste treatment costs [Schaschek 2006]. The German newspaper Freie Presse reported that 'the price for legal storage of one tonne of domestic waste is about 32 euros in the Czech Republic, while an incinerator in Saxony, for instance, requires 170 euros per ton. The storage of one ton of domestic electronic waste costs 180 euros in the Czech Republic and 350 euros in Germany. The prices at illegal dumps are even lower' [quoted in ČTK 2006c].

\section{Policy assessment: strengths and weaknesses}

The Germans already knew that it was difficult to enforce laws restricting crossboundary waste movement. In 1997, there were 40000 cases of reported environmental crimes in Germany, of which nearly 29600 were cases of unsafe waste management, including 58 cases of illegal transfrontier waste shipment. The police's success rate at solving environmental crimes in that year was $60 \%$ [Gallas and Werner 1998: 377].

Environmental offences in Germany, especially illegal waste transport violations, have rarely been prosecuted and punished because crimes most often go unreported and it is hard to find incriminating evidence. 'If a case comes before a public prosecutor despite these obstacles, the public prosecutor or the judge usually will stop investigations. In case a wrongdoer is actually sentenced, imprisonment is rarely imposed; in addition in most cases of imprisonment up to two years probation is granted. Usually a criminal ban on a professional activity is imposed in serious cases only, i.e. if there is a danger of recidivism. In 1996 there were two cases' [Gallas and Werner 1998: 378]. Federal environmental officials have identified a number of problems with current arrangements of German environmental crime enforcement. In general, they say it is difficult to prove guilt 
in environmental crimes. Within Germany, many officials lack training and qualifications for dealing with eco-crime, and cooperation between environmental authorities and the police is slow. In international cases, there is a lack of cooperation between competent authorities, in part because, rather than having a single national competent authority (CA) under the WSR, each German federal state has its own CA. There is also a language barrier. 'The legal situation becomes much more complicated and less known as the number of authorities and (within Europe) languages involved multiplies' [Gallas and Werner 1998].

Germany has long had a reputation as the biggest waste exporter in Europe and has sent waste both legally and illegally to many European nations. Waste from the Federal Republic of Germany was sent for disposal to the German Democratic Republic for many years before the end of communism. German waste exports to Eastern Europe have been widespread at least since the revolutions of 1989. Much of this transport has taken the form of 'dump and run' disposal, with Greenpeace Austria claiming that most of the trade in waste is illegal [Ram n.d.]. In the 1990s the European Commission determined that the German recycling system led to 're-dumping' in other European nations [Dopp 1997]. There were warnings early on that EU expansion could put Eastern European nations at risk of illegal waste transport. The German government itself warned of an inevitable 'suction effect' drawing waste from Western Europe, especially Germany, to the new member states [Czarnomski, Holmes and Webb 2006: 90]. Other European nations that have had problems with illegal or improper German waste imports since the early 1990s include France, Albania, Poland, Hungary, and Slovakia.

An examination of the many known cases of illegal German waste export over the last twenty years reveals patterns. Intense pressure within Germany caused by increasing waste generation and decreasing capacity create economic incentives to find quick and easy solutions. As a result, when Germans have sought to export waste, companies or individuals in the receiving nations have conspired to dispose of the waste cheaply, often in questionable ways. The recent appearance of black dumps in Bohemia follows this pattern.

\section{Discussion and conclusions}

While a great deal of media attention was devoted to the German waste issue in the first half of 2006, the question remains whether the transports will continue in the future. According to the Czech Customs Administration, illegal waste transports continued to be intercepted in 2007, though in fewer numbers than in $2006 .{ }^{5}$ Study of black dumping in Bohemia suggests that the waste transport policies and practices within individual nations and throughout the EU have contributed

\footnotetext{
${ }^{5}$ Personal interview with Lubomír Doskočil of the Czech Customs Administration in Prague, Czech Republic, 25 June 2007.
} 
to the phenomenon of illegal waste shipment, and until loopholes allowing free trade in waste labelled for recycling, coupled with weak enforcement, are remedied, there will continue to be a high probability of successful illegal transport. While it can be said that the illegal waste trade that led to the Bohemian black dumps is a product of economic incentives, those incentives are shaped by policies at the national and EU level. For the sake of discussion this section analyses the consequences, both intended and unintended, of existing policies in the context of the ToP theory.

\section{ToP insights into the Czech case}

Several conclusions can be drawn about the effects of current waste transport policies. While ToP provides a useful basis for understanding this case study, the theory may benefit from refinements to its interpretation of the environmental state.

\section{Illegal export was a predictable consequence of the 2005 German landfill rules}

It has already been noted that waste exports in the past occurred at times of limited German capacity. The possibility of illegal export to the Czech Republic was a predictable result of the recent landfill regulations - both theoretically from a ToP perspective, and empirically based on the long history of German waste exports. In 2002, as the June 2005 landfill reform deadline approached, 61 waste incinerators were operating in Germany. At that time, the incineration capacity could handle only $40 \%$ of the expected requirements for 2005 [Scottish Parliament Information Centre 2002: 22]. The OECD [2004] in 2004 pointed out that this low disposal capacity risked causing 'higher prices for waste disposal and exports of waste to neighbouring countries' [Ibid: 32]. This resulted in clear economic incentives to evade the new German law. The OECD explains that when materials are banned or redirected from landfills, which was the aim of the German legislation, 'the hope, of course, is that these products will, as a result, be recycled. But the incentive offered by the tax or ban is not an incentive to recycle, but rather an incentive to not landfill. Illegal dumping, exporting, and incineration are also stimulated' [Ibid.: 142]. Moreover, Hempen's [2005] analysis demonstrated that before 2005 authorities were able to calculate a waste processing shortfall of nearly two million tonnes caused by the new waste storage ordinance. The German association of incinerator operators (ITAD) warned before amendments to the EU's WSR took effect in 2007, 'If mixed green waste will not undergo a specific control, then it is expected, particularly for the Federal States at the eastern border, that an increasing amount of waste will be exported' [ITAD 2004].

From a ToP point of view, this raises questions about the sincerity of the German government's desire to enforce waste export law - in what may amount 
to a tacit collaboration between national authorities, municipalities, and/or businesses to reduce operational costs. Such an interpretation is consistent with the ToP hypothesis that governments and business often collaborate as a 'growth coalition' to promote economic activity at the expense of environmental quality [Schnaiberg 1980; Schnaiberg, Pellow and Weinberg 2002]. However, further research on this particular case of German waste import is required to test this hypothesis more definitively. At any rate, the lack of responsiveness and cooperation on the part of German authorities with their Czech counterparts shows that the Czech state faces constraints on its ability to protect public and environmental health from waste transports from abroad. ${ }^{6}$ Even when illegal transport could be foreseen, both national governments had difficulty stemming the flow.

\section{The export of waste shifts environmental risk from Germany to other nations and undermines sustainability principles}

ToP stresses that environmental issues involve issues of social equity, and the theory's critique of economic globalisation is relevant to understanding illegal waste transport. The proximity principle was articulated in large part due to the recognition that localities have a responsibility to manage their own waste and should not ship it elsewhere - whether legally or illegally. The polluter pays principle further reinforces the notion that waste producers should bear the burden of proper disposal and cleanup. Restrictions on export provide incentives for waste reduction or recycling. Unrestricted export means that producers may push waste processing risks on others, undermining EU and German principles of sustainable development. In this case, Germans have benefited at home from strict landfilling laws and Czechs have been made to bear the costs of disposal. In a globalised world, this makes the Czech Republic look like Germany's backyard refuse pile - in contradiction of the German CSCWMA, which touted the economic and ecological benefits of a closed product life-cycle. This law aimed to 'close the loop' between production and consumption, but the option of exporting waste defeats such goals by making the product life-cycle an open system. German waste export to Bohemia shifts the risk abroad and externalises the costs of production and consumption.

Not only is this an instance of waste flowing 'downhill' in a globalised world, but it highlights the ToP assertion that structural change is necessary for movement towards sustainability. 'Most "reasonable" scholars have taken revolutionary or even macrostructural change to the political economy off the agenda, as either unrealistic or impossible. They may be correct. In that context, the treadmill implies that the dream of solving environmental crises and achieving "sustainable development" is unlikely or impossible.' [Gould, Pellow and Schnaiberg 2004]

\footnotetext{
${ }^{6}$ Personal interview with Jitka Jenšovská of the Czech Environmental Inspectorate in Prague, Czech Republic, 18 July 2006.
} 


\section{Policy loopholes - intentional or not - make illegal transport easy and lucrative.}

Despite the social and ecological inequities that characterise the crime, it is simplistic to depict Germany as the villain and Bohemia as a purely innocent victim. Indeed, the Czech Environment Minister at the time, Libor Ambrozek, initially blamed the situation on Czechs who helped Germans bring the waste into the country. 'German businessmen often do not know that they are sending waste to the Czech Republic at variance with law', he said [ČTK 2006b]. The extent to which corruption on either side of the border may have contributed to the problem remains unclear.

As indicated earlier, illegal waste shipment in the EU is widespread and hard to deter and detect. This appears to be partly due to a business climate that promotes free trade, partly because waste is a difficult commodity to monitor and control, and partly because states prioritise other areas for law enforcement. One study by the network for the Implementation and Enforcement of Environmental Law (IMPEL) revealed that in October 2005 about $50 \%$ of inspected waste shipping out of the EU was illegal [Netherlands Ministry of Housing, Spatial Planning and the Environment 2005]. Another enforcement action found that of 88000 tonnes of waste bound for export $72 \%$ may have been illegal. Also, $93 \%$ of the documents authorising transport were irregular in some way, and there was only a $6 \%$ probability of an illegal waste shipment being detected by law enforcement authorities [Roelofs 2006]. As they schemed to enter Bohemia, waste smugglers were able to forge documents or mislabel municipal waste as recyclable material. With the Czech accession to the EU these smugglers could expect limited or non-existent border checks.

The existence of loopholes and institutional obstacles to the effective enforcement of waste transport rules shows that the ToP theory may inadequately theorise how the state functions in its role as protector of environmental quality and human health. Not only may the state lack the will to protect the environment, but there may be practical constraints to enforcing the law even when the will is present. Moreover, the Czech case demonstrates that there is a scale issue involved, because different levels of government may have different interests in environmental policy and enforcement. In this respect, there has been conflict between local and central authorities within the Czech Republic, and between nation states and the EU. Locals living in the affected areas of Bohemia had an understandably negative experience of illegal waste import. But some municipal and regional governments have expressed support for changes in the law which would allow more waste to be imported legally for incineration. The city councils of Liberec and Brno have lobbied to allow German waste to be burned in their municipal incinerators. But the central government has consistently opposed illegal or legal waste import.

At the international level, while the WSR calls for cooperation between national competent authorities, the Czech and German states have clashed over 
how to resolve the black dump question. Meanwhile, at the EU-level some states and the incineration industry are now lobbying to allow unfettered trade in waste for use as an energy source. This shows that the 'environmental state' may not be a monolithic institution, and interests compete to influence environmental policy at different levels of governance. Therefore, the ToP theory should be further developed to account for variability in environmental protection within the state.

\section{Future directions for research}

Further research is needed to better understand the issue of waste imports in the Czech Republic, which is an ongoing phenomenon, and to test how the ToP theory applies to the situation. It would be educational to do fieldwork in the affected region, including interviewing locals about their experiences. It is also an open question to what degree public and private corruption within the Czech Republic, and between Czechs, Germans and possibly others, plays a role in the illegal transport business. The situation must be analysed within the context of a changing EU policy milieu, as the European Court of Justice interprets existing rules and a new framework directive on waste and a separate thematic strategy on the prevention and recycling of waste are being debated in Brussels.

Benjamin VAIL, a native of the United States, is a lecturer in the Sociology Department and a PhD student in the Environmental Studies Department at Masaryk University. He received his Masters degree in sociology from the University of Wisconsin-Madison and his Bachelor degree in history from Carleton College in the United States. His recent scientific publications include 'Ecological Modernisation at Work? Environmental Policy Reform in Sweden at the Turn of the Century', forthcoming in Scandinavian Studies.

\section{References}

Andersson, M. 1999. M. Change and Continuity in Poland's Environmental Policy. Dordrecht, Netherlands: Kluwer Academic Publishers.

Betts, M., P. Novak and T. Young. 2002. Waste Management Plan for the Czech Republic: Final Report, Volume 2 - Actions Required for Completion of National Waste Management Plan. Abingdon, UK: AEA Technology Environment. Retrieved 19 March 2007 (http: //ec.europa.eu/environment/enlarg/pdf/reap/reap_report_annex3_czech_waste_ en.pdf).

Buttel, Frederick H. 2004. 'The Treadmill of Production: An Appreciation, Assessment, and Agenda for Research.' Organization and Environment 17 (3): 323-336.

Cowan, Rick and Douglas Century. 2003. Takedown: The Fall of the Last Mafia Empire. New York: Berkley Books.

ČTK. 2006a. Some 15000 Tonnes of German Waste Stored in Czech Republic. 14 February 2006. 
ČTK. 2006b. Paroubek to Write to Merkel over Illegal Waste. 22 February 2006.

ČTK. 2006c. Saxony to Alert Czechs about Suspicious Lorries with Waste. 7 April 2006.

ČTK. 2006d. Waste Smugglers Arrested. 20 April 2006.

ČTK. 2006e. Czechs say Libčeves Waste Dangerous, Germans Disagree. 4 May 2006.

ČTK. 2006f. V4 Countries Agree on Joint Procedure against Waste Import. 5 May 2006.

ČTK. 2006g. Inspection Wants to Fine Germans for Illegal Waste Imports. 12 June 2006.

ČTK. 2006h. Czechs Try in EU to Prevent Import of Waste. 27 June 2006.

Czarnomski, S., A. Holmes and B. Webb. 2006. 'IMPEL-TFS Threat Assessment Project: The Illegal Shipment of Waste among IMPEL Member States.' London: Jill Dando Institute of Crime Science, University College London. Retrieved 30 March 2007 (http://ec.europa.eu/environment/impel/pdf/tfs_threat_report.pdf).

Czech Ministry of the Environment. 2003. Waste Management Plan of the Czech Republic. Prague.

Czech Ministry of the Environment. 2007. Statistical Environmental Yearbook of the Czech Republic 2006. Retrieved 23 October 2007 (http://www.env.cz/www/dav.nsf/ rocenka_06/06_titul.htm).

Dopp, J. L. 1997. 'German Municipal Waste and EC Waste Policy.' Washington, DC: American University Trade \& Environment Database Case Studies, Vol. 7, No. 2. Retrieved 3 March 2007 (http://www.american.edu/TED/msweu.htm).

European Commission. 2005. 'Supervision and Control of Shipments of Waste.' Retrieved 27 October 2006 (http://europa.eu/scadplus/leg/en/lvb/111022.htm).

Gallas, A. and J. Werner. 1998. 'Transboundary Environmental Crimes: German Experiences and Approaches.' Paper presented at the 5th International Conference on Environmental Compliance and Enforcement. Monterey, California, November 1998.

Gould, Kenneth A., David N. Pellow and Allan Schnaiberg. 2004. 'Interrogating the Treadmill of Production: Everything You Wanted to Know about the Treadmill but Were Afraid to Ask.' Organization \& Environment. 17 (3): 296-316.

Hansen, W., M. Christopher and M. Verbuecheln. 2002. 'EU Waste Policy and Challenges for Regional and Local Authorities.' Berlin: Ecologic Institute for International and European Environmental Policy. Retrieved 26 March 2007 (http://www.ecologic. de/download/projekte/1900-1949/1921-1922/1921-1922_background_paper_waste_ en.PDF).

Hempen, S. 2005. 'History and Current Status of Waste Management in Germany.' Presentation at the conference on the Future of Residual Waste Management in Europe. Retrieved 27 February 2007 (http://www.orbit-online.net/orbit2005/ vortraege/hempen-ppt.pdf).

ITAD (Interessengemeinschaft der Thermischen Abfallbehandlungsanlagen in Deutschland). 2004. Country Report: Germany. Confederation of European Waste-toEnergy Plants (CEWEP) Congress, Amsterdam, 7-8 September 2004. Retrieved 27 February 2007 (http://www.cewep.com/storage/med/media/creports/11_germany. pdf?fCMS=1b07ba11b1652b40175e088daf6dfbe9).

Klíma, Ivan. 1990. Love and Garbage. London: Vintage.

Massari, M. (ed.) 2003. 'Illegal Trafficking in Hazardous Waste in Italy and Spain: Final Report.' Legambiente: Rome. Retrieved 24 October 2007 (http://www.legambiente. eu/documenti/2004/0709_ecomafia_italia_spagna/ecomafia_italia_spagna_EN.pdf).

McCormick, J. 2001. Environmental Policy in the European Union. New York: Palgrave.

Netherlands Ministry of Housing, Spatial Planning and the Environment. 2005. Illegal Waste Shipments in Europe. The Hague: The Ministry of VROM.

OECD (Organization for Economic Cooperation and Development). 2004. Addressing the Economics of Waste. Paris: OECD. 
Ram, P. J. [No date]. ‘German Waste Exports.' Washington, DC: American University Trade \& Environment Database Case Studies. Retrieved 3 March 2007 (http://www. american.edu/TED/germhaz.htm).

Roelofs, J. 2006. 'IMPEL Waste Transport Inspections: A Step towards European Enforcement.' Paper presented at the 16th Regional Workshop on Illegal Traffic, Bratislava, Slovakia, October 2006.

Royte, Elizabeth. 2005. Garbageland: On the Secret Trail of Trash. New York: Little, Brown \& Co.

Schaschek, S. 2006. 'Waste Wars: Authorities Find German Firms Are Dumping Illegally.' The Prague Post. 22 February 2006.

Schnaiberg, Allan. 1980. The Environment: From Surplus to Scarcity. New York: Oxford University Press.

Schnaiberg, Allan and Kenneth Alan Gould. 1994. Environment and Society: The Enduring Conflict. New York: St. Martin's Press.

Schnaiberg, A., D. N. Pellow and A. S. Weinberg. 2002. 'The Treadmill of Production and the Environmental State.' Pp. 15-32 in The Environmental State under Pressure, edited by Arthur Mol and Fred Buttel. Kidington, Oxford, UK: Elsevier Publishing.

Scottish Parliament Information Centre. 2002. 'Waste Policy: An Overview.' Retrieved 9 March 2007 (http://www.scottish.parliament.uk/business/research/pdf_res_brief/ sb02-25.pdf).

Weinberg, Adam S., David N. Pellow, and Allan Schnaiberg. 2000. Urban Recycling and the Search for Sustainable Community Development. Princeton, New Jersey: Princeton University Press.

Vail, Benjamin J. 2005. 'Czech Republic on an Environmental See-saw: Free Market Reforms Solve Some Environmental Problems, Cause Others.' Times Record. 15 June 2005.

Zegnál, J. 2006. 'EU Changing Rules on Waste Transportation.' Czech Business Weekly. 29 May 2006. 